\title{
Impact of Backyard Poultry Farming on Extension and Communication Behaviour of Tribal Farmers: A study of Koraput District, Odisha, India
}

\author{
J. Mishra, B. C. Das*, P. Swain and K. Shweta \\ Department of Veterinary and Animal Husbandry Extension, College of Veterinary Science \\ and Animal Husbandry, Odisha University of Agriculture and Technology \\ Bhubaneswar, Odisha, India \\ *Corresponding author
}

\section{A B S T R A C T}

\section{Keywords}

Backyard poultry farming,

Livelihood, Tribal,

Extension and

communication

\section{Article Info}

Accepted:

15 August 2020

Available Online:

10 September 2020
Backyard poultry rearing is a very common practice in the rural areas. It is reared by the poorest of the poor farmers to the better off farmers of the community. Backyard poultry farming is popular in the country due its economic, employment and nutritional importance. In spite of its huge contribution to rural livelihood not much interest has been shown by the farmers to scale up the production process. Present investigation was carried out to know the impact of backyard poultry farming on extension and communication behaviour of the tribal farmers which is an important factor for scaling up of backyard poultry farming in rural areas. Koraput district of Odisha was selected purposively for this study and 160 tribal poultry farmers were selected randomly form eight randomly selected villages. The study revealed that there is low level of extension and communication impact on $46.26 \%$ of the beneficiaries and high level impact on $38.12 \%$ of the beneficiaries. The correlation of selected socio-economic variables with the impact on extension and communication behaviour revealed that education level of the farmers is highly significant with the extension and communication behaviour whereas it had negative correlation with age, family size, livestock possession of the respondents. However, it had positive correlation with land holding and annual income.

\section{Introduction}

Indigenous poultry rearing is a very common practice in the rural areas. It is reared by the poorest of the poor farmers to the better off farmers of the community. Backyard poultry farming is popular in the country due its economic, employment and nutritional importance. Poultry is a survival tool for the poorest of the poor during financial crisis.
Over 3.8 million metric tons of poultry meat was consumed across India in 2019. The per capita availability of eggs from 1950-51 to 2018-19 has increased from 5 to 79 per annum (Basic A.H \& Fisheries statistics, 2019, DAHD, GOI). The Poultry Industry provides direct or indirect employment to more than 3.2 million people. The total egg production in the country is 103.32 billion numbers. A huge $95 \%$ of the total egg 
production is contributed by poultry and the rest are produced by duck and other birds. The total number of poultry birds in the country is 851.81 million in 2019 , which has registered an increase of $16.8 \%$ from the $19^{\text {th }}$ livestock census. However, the data is very scanty on the contribution backyard poultry farming to the economy.

In our country, the growth of commercial poultry has been no doubt significant over the years. On the other hand backyard poultry production has been rising steadily and there is growing preference among the consumers towards the backyard poultry meat and egg. The backyard poultry is predominantly rural based and can be started with a meagre investment of a few hundreds of rupees to meet economic, rituals and nutritional needs of present and future. Small family poultry flocks represent a very vital source of income for poor rural households. Poultry rearing is often considered as supplementary to other livelihood activities. Birds serve as a buffer against shocks of bad harvests and support in dire need of money because they can easily be sold anytime for cash. The investment being very low, poultry keeping in the backyard gives very high return. Sale of eggs and meat can generate income for the farmers. The growth of backyard poultry over the years is very encouraging in the state of Odisha. There is rising interest among the rural farmers for backyard poultry farming in general and tribal farmers in particular. Besides economic benefit, the tribal famers also rear the indigenous birds for cultural and religious purposes (Mishra et al., 2020 and Nayak et $a l ., 2020)$. Indigenous poultry can be found in most of the rural households in tribal Koraput district of Odisha. They are reared both by the landless as well as affluent land holders. There is high demand of indigenous poultry meat in the State and the birds are sold in premium price. In spite of all these advantages of indigenous poultry rearing, the tribal poultry rearers of Koraput district are found unable to derive desired income from this occupation. Their poor status is reflected in their poor socio-economic condition. The present paper discusses the impact of backyard poultry farming on extension and communication behaviour of the tribal farmers of Koraput district of Odisha.

\section{Materials and Methods}

The study was conducted in purposively selected Koraput district of Odisha. From this district, two blocks were selected randomly and from these two blocks, two Gram Panchayats were selected randomly. Thereafter, from each Gram Panchayat, two villages were selected randomly and from each village, twenty poultry farmers having more than 20-25 indigenous poultry were selected randomly. The total 160 tribal poultry farmers selected from the district constituted the sample size. Impact on extension and communication behaviour was measured with the help of 10 statements developed for the purpose which were validated by highly experienced professor cadre experts of different departments of College of Veterinary Science \& Animal Husbandry and senior officers of Fisheries and Animal Resource Development Department, Govt. of Odisha. A five point Likert type scale with points suitable for corresponding variable was incorporated in the interview schedule with scores on a continuum with 1 (strongly disagree) to 5 (strongly agree) for each of the 10 statements. In measuring the impact on communication and extension behaviour of beneficiaries, their exposure to mass media and cosmopolitan behaviour is taken into account. Besides these, their interaction with government officials, medicine and feed dealers and approach to banks for availing credit are taken into account. Also their ability to bargain with purchaser for better pricing of poultry is taken 
into account. The responses of the respondents were recorded in a five-point continuum scale and then summated. Interview schedule was prepared as per the objectives of the research study and it was pilot tested. The poultry farmers were surveyed with the help of pretested interview schedule. The collected data were compiled, tabulated and analysed using frequency, percentage, mean score, etc.

\section{Results and Discussion}

\section{Impact on extension and communication behaviour}

Extension and communication behaviour is the ability to communicate improved scientific innovations for improvement of living standard. So in this study, 10 statements were formulated carefully judging the communication ability of the farmers with fellow farmers, feed, medicine and meat retailers as well as banks for approaching credit which will have a direct impact on his livelihood. These ten questions were asked to 160 farmers and their responses were collected on a five-point scale (5 to 1) (Table 1).

Analysis of data relating to communication impact on the respondents revealed that 31.87 $\%$ of the respondents had expressed their disagreement that their exposure to the radio, $\mathrm{TV}$, newspaper, etc., has increased due to goat farming whereas only $14.37 \%$ agreed to the question. The mean score of the statement was 1.87 . To a question, whether their contact with departmental officials and PRI members has increased, $43.75 \%$ agreed whereas $40 \%$ disagreed to the statement, and the mean score of the statement was 2.97. $42.5 \%$ farmers agreed to the statement of increased visit to town due to goat farming whereas $18.75 \%$ disagreed to the statement and the mean score of the statement was 3.3. When a question was asked that due to backyard poultry farming whether their frequency of viewing poultry related programme has increased, $63.75 \%$ strongly disagreed to the statement and only $11.25 \%$ respondent agreed to this statement, and mean score of the statement was 1.68. To the question on your ability to interact with medicine and feed dealers, $42.5 \%$ disagreed to the statement whereas $25 \%$ disagreed and 2.55 was the mean score of the statement. $40.62 \%$ of the respondents agreed to the statement that their ability to approach to bank and other financial institutions for availing credit has increased whereas $29.37 \%$ of the respondents disagreed to the statement, and 2.7 was the mean score of the statement.50\% of the respondents agreed to the statement that their ability to bargain with poultry meat retailer for better pricing has developed whereas $14.37 \%$ of the respondents disagreed to the statement, and 3.77 was the mean score of the statement. $29.37 \%$ of the beneficiaries expressed their ability to travel to cities for attending agricultural exhibitions where as $33.12 \%$ expressed their inability especially to state headquarters having 2.45 mean score of this statement. Majority of farmers $(51.87 \%)$ agreed that they could demonstrate and speak better management practices of backyard poultry farming to villagers, and the mean score was 3.52 of this statement. Because of all these travelling, trainings, demonstrations and interactions, they are better developed as a communicator and able to maintain good relationship with various stakeholders. $43.12 \%$ of the respondents agreed that their skill of interpersonal relationship has developed due to goat farming, however, $18.12 \%$ disagreed to the statement, and 3.77 was the mean score of the statement. The overall mean score for impact on communication and extension behaviour of beneficiaries was 28.84 . 
Table.1 Responses of the respondents to the statements of extension and communication behaviour

\begin{tabular}{|c|c|c|c|c|c|c|c|}
\hline \multirow{2}{*}{$\begin{array}{l}\text { Sl. } \\
\text { No. }\end{array}$} & \multirow[t]{2}{*}{ Statements } & \multicolumn{6}{|c|}{ Response } \\
\hline & & SA & $\mathbf{A}$ & UD & DA & SD & Mean \\
\hline \multirow[t]{2}{*}{1} & My exposure to radio, TV, & 3 & 23 & 4 & 51 & 79 & \multirow[t]{2}{*}{1.87} \\
\hline & $\begin{array}{l}\text { Newspaper, etc., has } \\
\text { increased }\end{array}$ & 1.87 & 14.38 & 2.5 & 31.88 & 49.37 & \\
\hline \multirow[t]{2}{*}{2} & \multirow{2}{*}{$\begin{array}{l}\text { Frequency of contacting } \\
\text { veterinary and PRI officials } \\
\text { has increased }\end{array}$} & 6 & 70 & 9 & 64 & 11 & \multirow[t]{2}{*}{2.97} \\
\hline & & 3.75 & 43.75 & 5.63 & 40.00 & 6.87 & \\
\hline \multirow[t]{2}{*}{3} & \multirow{2}{*}{$\begin{array}{l}\text { My visit to town has } \\
\text { increased than before }\end{array}$} & 17 & 68 & 33 & 30 & 12 & \multirow[t]{2}{*}{3.30} \\
\hline & & 10.63 & 42.5 & 20.63 & 18.75 & 7.5 & \\
\hline \multirow[t]{2}{*}{4} & \multirow{2}{*}{$\begin{array}{l}\text { Frequency of watching } \\
\text { poultry related programmes } \\
\text { in TV is increased }\end{array}$} & 3 & 18 & 6 & 31 & 102 & \multirow[t]{2}{*}{1.68} \\
\hline & & 1.87 & 11.25 & 3.75 & 19.37 & 63.75 & \\
\hline \multirow[t]{2}{*}{5} & \multirow{2}{*}{$\begin{array}{l}\text { Ability to interact with } \\
\text { medicine and feed dealers is } \\
\text { developed }\end{array}$} & 12 & 40 & 6 & 68 & 34 & \multirow[t]{2}{*}{2.55} \\
\hline & & 7.5 & 25 & 3.75 & 42.5 & 21.25 & \\
\hline \multirow[t]{2}{*}{6} & \multirow{2}{*}{$\begin{array}{l}\text { Ability to approach bank } \\
\text { and other financial } \\
\text { institution for availing } \\
\text { credit is developed }\end{array}$} & 16 & 65 & 4 & 47 & 28 & \multirow[t]{2}{*}{2.96} \\
\hline & & 10 & 40.62 & 2.5 & 29.37 & 17.5 & \\
\hline \multirow[t]{2}{*}{7} & \multirow{2}{*}{$\begin{array}{l}\text { Capability to bargaining } \\
\text { with poultry meat retailers } \\
\text { for better pricing of my } \\
\text { birds is developed }\end{array}$} & 38 & 80 & 14 & 23 & 5 & \multirow[t]{2}{*}{3.77} \\
\hline & & 23.75 & 50 & 8.75 & 14.37 & 3.13 & \\
\hline \multirow[t]{2}{*}{8} & I am able to travel to & 5 & 47 & 8 & 53 & 46 & \multirow[t]{2}{*}{2.45} \\
\hline & $\begin{array}{l}\text { districts headquarter and } \\
\text { state head quarter for } \\
\text { attending agricultural } \\
\text { exhibitions }\end{array}$ & 3.125 & 29.37 & 5 & 33.13 & 28.75 & \\
\hline \multirow[t]{2}{*}{9} & \multirow{2}{*}{$\begin{array}{l}\text { Able to demonstrate and } \\
\text { speak better managemental } \\
\text { practices of backyard } \\
\text { poultry farming to villagers }\end{array}$} & 24 & 83 & 9 & 40 & 4 & \multirow[t]{2}{*}{3.52} \\
\hline & & 15.00 & 51.87 & 5.63 & 25.00 & 2.50 & \\
\hline \multirow[t]{2}{*}{10} & \multirow{2}{*}{$\begin{array}{l}\text { The skill of interpersonal } \\
\text { relationship among the } \\
\text { stake holders has been } \\
\text { developed }\end{array}$} & 42 & 69 & 19 & 29 & 1 & \multirow[t]{2}{*}{3.77} \\
\hline & & 26.25 & 43.13 & 11.87 & 18.13 & 0.62 & \\
\hline & Mean Score $\quad 28.84$ & & & & & & \\
\hline \multicolumn{8}{|c|}{ Standard Deviation 1.35} \\
\hline
\end{tabular}

(Figures in the first line represent frequency and second line \% under each row) 
Table.2 Distribution of beneficiaries as per impact on extension and communication behaviour

\begin{tabular}{|c|c|c|c|c|}
\hline \multicolumn{3}{|c|}{ Impact on Extension and Communication Behaviour } & & \multirow{5}{*}{$\begin{array}{l}\text { Maximum } \\
\text { score=50 } \\
\text { Minimum } \\
\text { score=10 } \\
\text { Mean=28.84 } \\
\text { S.D.=1.35 }\end{array}$} \\
\hline Sl. No & Impact range & Frequency & Per cent & \\
\hline 1 & $\begin{array}{l}\text { High level impact } \\
(\text { Mean+1S.D) } \\
(>30.19)\end{array}$ & 61 & 38.12 & \\
\hline 2 & $\begin{array}{l}\text { Medium level income } \\
(\text { Mean+1S.D) to (Mean-1S. D) } \\
(30.19-27.49)\end{array}$ & 25 & 15.62 & \\
\hline 3 & $\begin{array}{l}\text { Low level impact } \\
(\text { Mean-1S. D) } \\
(<27.49)\end{array}$ & 74 & 46.26 & \\
\hline
\end{tabular}

Table.3 Correlation analysis of selected socio-economic variables with extension and communication behaviour impact

\begin{tabular}{|l|l|l|}
\hline SI No. & Independent Variables & Correlation Coefficient (r) \\
\hline $\mathbf{1}$ & Age & -0.121 \\
\hline $\mathbf{2}$ & Education & $0.305^{* *}$ \\
\hline $\mathbf{3}$ & Family Size & -0.002 \\
\hline $\mathbf{4}$ & Livestock Possession & -0.045 \\
\hline $\mathbf{5}$ & Land Holding & 0.074 \\
\hline $\mathbf{6}$ & Annual Income & 0.122 \\
\hline
\end{tabular}

(*5\% level of significance, $* * 1 \%$ level of significance)

Figure.1 Level of extension and communication behaviour

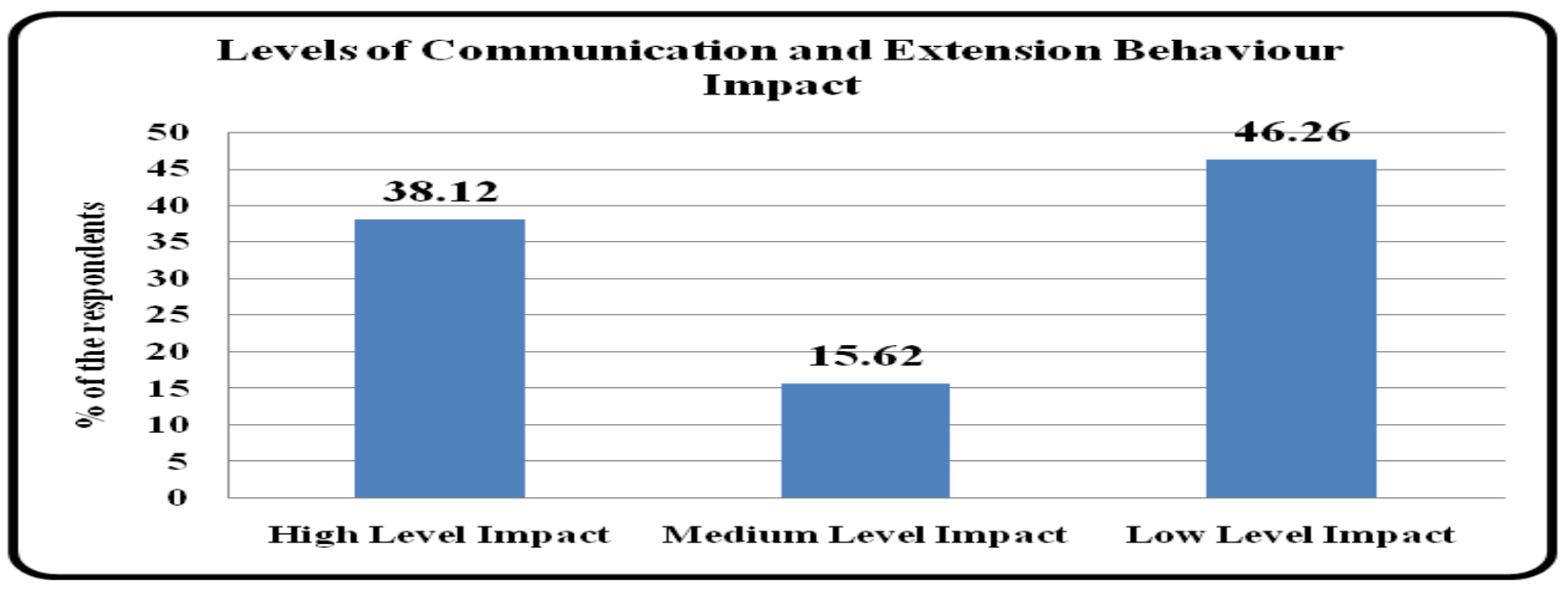

The analysis related to distribution of respondents on the basis of level of impact on communication and extension behavior of beneficiaries presented in table 2 and figure 1 revealed that there is low level of impact on $46.26 \%$ of the beneficiaries and high level impact is on $38.12 \%$ of the beneficiaries. So there is a little improvement in the 
communication abilities of beneficiaries and lots more is expected with experience and exposure. This study does not report pleasant conclusion on impact of backyard poultry on communication and extension behaviour of the tribal farmers. Nchinda et al., (2011) reported enhanced social interaction and solidarity among poultry project participants. Patel et al., (2014) assessed the after effects of backyard poultry farming on tobacco chewing habit of the respondents that showed a drastic behavioural change with decrease in the number of addicts. Dhaka et al., (2017) and Kanwat et al., (2012) both reported increase of favourable attitude towards backyard poultry after the respondents were introduced to backyard poultry. Kavita and Rajkumar (2017) observed in their studies that the respondents had favourable attitude towards backyard poultry farming and their information seeking behaviour has improved.

\section{Correlation analysis of socio-economic variables with communication and behavioural impact}

The selected socio-economic variables are subjected to correlation with the social impact and the findings are presented in the table 3.

The analysis of the data presented in the table 3 revealed that extension and communication behavioural impact had significant correlation with education at $1 \%$ level of significance whereas it had negative correlation with age, family size, livestock possession of the respondents. However, it had positive correlation with land holding and annual income.

In conclusion, the result obtained from this study signifies that there is not much change in extension and communication behaviour of the tribal poultry farmers due to backyard poultry rearing. To improve their living standard, more skill training and exposure visits of the farmers may be organised by the developmental departments of Koraput district. The exposure visits and interactions with extension agents will change their outlook towards the backyard poultry farming, and they may adopt scientific practices to get maximum benefit to support their livelihood.

\section{References}

Basic Animal Husbandry and Fishery Statistics .2019. Government of India. Department of Animal Husbandry, Dairying and Fisheries, Krishi Bhavan, New Delhi, India,

Deka, P., Borgohain, R. and Deka, B. 2013. Status and constraints of backyard poultry farming amongst tribal community of Jorhat district in Assam. The Asian J Anim Sc., 8(2): 86-91.

Kanwat, M., Meena, M.S., Kumar, P.S., Choudhary, V.K. and Bhagawati, R. 2012. Measurement of attitude towards the adoption of back yard poultry farming in Arunachal Pradesh. J. Agri. Sci., 4(3): 131-136.

Mishra, J., Das, B. C. and Sardar. K. K.2020. Sacrifice of Poultry Birds by Tribals of Koraput District of Odisha, India, Int.J.Curr.Microbiol.App.Sci (2020) 9(3): 2153-2158

Nayak, G D., Sardar, K. K. and Das, B. C. 2020. Socio-economic Condition of Khadia Poultry Farmers and Phenotypic Characteristics of Khadia Chicken of Northern Odisha, India, Int.J.Curr.Microbiol.App.Sci. $\quad$ 9(1): 1395-1404

Nchinda, V.P., Thieme, O., Ankers, P., Crespi, V. and Ariste, S. 2011. Food security and economic importance of family poultry (chicken) husbandry program in Artibonite and South departments of Haiti. Livestock Research for Rural Development. 23(9). 
Patel, S.K., Machhar, R.G., Kacha, H.L., Rani, R.R., Patel, G.D. and Patel U.M. 2014. Effect of Backyard Poultry Farming on Living Standard of Tribal Farmers in Dahod District of Gujarat, India. Journal of Poultry Science and
Technology, 2(4): 79-83.

Rajkumar, U., Rama Rao, S.V., Sharma, R.P. 2010. Backyard poultry farmingchanging the face of rural and tribal livelihoods. Indian Farming. 59:20-24.

\section{How to cite this article:}

Mishra, J., B. C. Das, P. Swain and Shweta, K. 2020. Impact of Backyard Poultry Farming on Extension and Communication Behaviour of Tribal Farmers: A study of Koraput District, Odisha, India. Int.J.Curr.Microbiol.App.Sci. 9(09): 2015-2021.

doi: https://doi.org/10.20546/ijcmas.2020.909.251 